

\section{Panduan Bimbingan Penulisan}

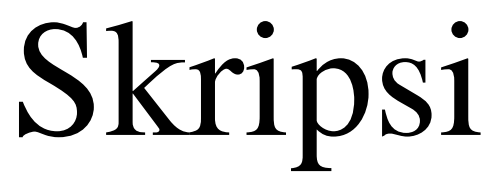

\section{Dr. Jeffrit Kalprianus Ismail, M.Pd.K Dewi Yuliana, M.Th.,M.Pd.K}

\section{Editor}

Semy Djulandy Balukh

Seprianus L. Padakari

Penerbit STAK Arastamar Jayapura 2020 


\section{PANDUAN BIMBINGAN PENULISAN SKRIPSI \\ Jeffrit Kalprianus Ismail dan Dewi Yuliana \\ Copyright () 2020}

Editor: Semy Djulandy Balukh dan Seprianus L. Padakari

Desain Sampul

\& Penata Letak: Jeffrit K. Ismail

Gambar Sampul: Google Image

Katalog dalam Terbitan (KDT)

Ismail, Jeffrit Kalprianus \& Yuliana, Dewi

\section{PANDUAN BIMBINGAN PENULISAN SKRIPSI}

Jeffrit Kalprianus Ismail \& Dewi Yuliana; editor Semy Djulandy Balukh \& Seprianus L. Padakari

-cet. 1 - Jayapura: STAK Arastamar Jayapura, 2019; 14,8 cm x $21 \mathrm{~cm}$

ISBN: 978-623-91787-4-1

Hak Cipta Terbitan pada

Penerbit STAK Arastamar Jayapura

J1. Ifar Gunung No. 70, Sentani Kota

Telp. 081344000351

e-mail: stakgrimenawa@gmail.com

Hak cipta dilindungi oleh Undang-undang

Cetakan Pertama: 2020 


\section{KATA PENGANTAR}

Penulisan karya ilmiah di perguruan tinggi, merupakan kewajiban mahasiswa yang sedang menempuh studi. Di akhir studi jenjang S-1, skripsi adalah karya tulis ilmiah yang harus dihasilkan oleh mahasiswa berdasarkan penelitian yang dilakukan secara mandiri.

Skripsi dibuat berdasarkan ketentuan institusi dan dilakukan oleh mahasiswa yang telah dinyatakan memenuhi persyaratan akademik dan ketentuan yang berlaku.

Sebelum melakukan penelitian (skripsi), mahasiswa diwajibkan mengajukan judul dan proposal skripsi. Judul yang diusulkan akan dicek oleh Bidang Akademik untuk melihat apakah jenis penelitian yang diajukan sudah dilakukan oleh peneliti terdahulu, atau belum. Pengajuan proposal skripsi diarahkan oleh Dosen Pembimbing yang telah ditetapkan oleh Bidang Akademik.

Setelah proposal diajukan kepada Bidang Akademik, maka selanjutnya proposal tersebut diseminarkan secara terbuka (di kampus) pada seminar proposal untuk mendapatkan masukan atau persetujuan dari para dosen yang ikut dalam seminar proposal dimaksud.

Apabila proposal penelitian skripsi disetujui maka mahasiswa dapat melanjutkan ke tahap beriktunya yaitu penelitian. Selama masa penelitian, mahasiswa wajib melakukan pertemuan dengan Dosem Pembimbing untuk membicarakan hal-hal teknis maupun substansial terkait 
dengan tindakan penelitian yang dilakukan mahasiswa bersangkutan.

Hasil-hasil penelitian disusun dalam bentuk naskah skripsi. Setelah selesai penyusunan skripsi, maka sesuai dengan batas waktu yang ditentukan Bidang Akademik, mahasiswa mendapatkan jadwal ujian skripsi dengan dosendosen penguji yang akan menguji skripsi yang bersangkutan. Penyusunan dan penulisan skripsi itu sendiri haruslah mengikuti ketentuan yang berlaku, yang ditetapkan oleh pihak institusi. Buku ini adalah ketentuan penyusunan dan penulisan skripsi yang dikeluarkan oleh institusi Sekolah Tinggi Agama Kristen Arastamar Grimenawa Jayapura.

Buku pedoman ini disusun untuk kepentingan mahasiswa yang akan menyusun skripsi dan untuk menyeragamkan proses penulisan skripsi. Hal ini dilakukan untuk mempermudah mahasiswa dalam menyusun skripsi (berdasarkan hasil penelitiannya). Mahasiswa STAK Arastamar Grimenawa Jayapura hendaknya mengikuti ketentuan yang dijelaskan dalam buku ini.

Semoga dapat bermanfaat.

Salam,

Penulis 


\section{DAFTAR ISI}

1 Pendahuluan -1

2 Persyaratan dan Prosedur Penyusunan Skripsi - 7

3 Usulan Proposal Skripsi- 11

4 Seminar Proposal Skripsi - 23

5 Penyusunan Skripsi - 25

6 Dosen Pembimbing dan Syarat-syaratnya - 34

7 Batas Waktu Bimbingan Skripsi -36

$8 \quad$ Ujian Skripsi - 38

9 Tata Cara Penulisan - 44

10 Hasil Penelitian dan Pembahasan - 87

11 Hak dan Kewajiban - 88

12 Lampiran-Lampiran - 91

Daftar Pustaka - 115 


\section{BAB 1 \\ PENDAHULUAN}

Menulis adalah sebuah tindakan yang memiliki ragam latar belakang. Dalam perguruan tinggi, menulis adalah suatu kewajiban. Hal ini tampak dari tugas-tugas membuat makalah, bedah buku, review buku, dan pada tahap akhir dari studi adalah penyusunan skripsi (untuk jenjang S-1), tesis (untuk jenjang S-2), dan disertasi (untuk jenjang S-3).

Menulis memiliki beragam ketentuan untuk semua jenis karya ilmiah. Ketentuan tersebut merupakan sebuah keputusan yang dikeluarkan oleh lembaga penyelenggara pendidikan. Karya tulis ilmiah adalah sebuah hasil penelitian, pemikiran, dan pemahaman akan fakta lampau, fakta kini, dan harapan di masa depan yang akan menjadi sebuah keputusan keilmuan.

Ketentuan atau aturan main mengenai pedoman penulisan karya ilmiah di semua jenjang pendidikan mengarahkan setiap mahasiswa (penulis atau peneliti) untuk memperhatikan rambu-rambu penulisan sehingga tulisan itu sendiri dalam menghasilkan sebuah struktur berpikir, fakta penelitian, dan realisasi (penerapan) hasil penelitian yang dilakukan oleh mahasiswa. 
Kita tahu bahwa menulis karya ilmiah tidaklah semudah yang kita pikirkan. Pemahaman akan substansi tulisan, struktur berpikir, pemahaman akan fakta penelitian, tata cara penulisan, adalah kesatuan yang tak dapat dipisahkan. Dari situ kita dapat memahami kualitas tulisan yang dapat memberikan pengaruh bagi para pembaca dan masyarakat di mana hasil penelitian itu diterapkan.

Buku ini secara khusus menjelaskan mengenai panduan bimbingan penulisan skripsi. Panduan bimbingan ini dibuat agar mahasiswa yang sedang menyusun skripsi (hasil penelitian lapangan, perpustakaan, dan sebagainya), dapat menunjukkan kualitas tulisan itu sendiri. Dengan demikian, panduan bimbingan penulisan skripsi sangat penting dipahami dan diterapkan di perguruan tinggi.

Setiap perguruan tinggi memiliki ketentuan atau pedoman tersendiri; kadang sama dengan perguruan tinggi lainnya, dan kadang juga berbeda. Tetapi secara substansial, setiap panduan memiliki kandungan dan prinsip yang sama, tergantung metode penulisan seperti apa yang digunakan, mekanisme penulisan struktur penelitian, dan aspek-aspek lainnya yang signifikan dan suplementatif.

Melihat perkembangan teknologi informasi dan ilm pengetahuan, kita tersadar bahwa kita harus terus mengasah kemampuan untuk dapat bersaing di dunia kerja. Hasil-hasil penelitian para mahasiswa mencerminkan kemampuan dasar dan kemampuan intelektualnya sebagai bekal di kemudian hari. Jika hasil penelitiannya kurang baik, maka dapat 
berpotensi mengurangi kapabilitas akademis dan pemahaman tentang kajian keilmuan yang digelutinya. Dunia kerja mendorong setiap orang untuk berkompetensi secara sehat, tidak hanya soal kapabilitas fisik, melainkan kapabilitas relasi, komunikasi, dan akademis. Apalagi, mahasiswa itu sendiri telah mengenyam pendidikan selama bertahun-tahun.

Dengan memperhatikan berbagai kepentingan terkait dengan pengembangan dan keteratur pemahaman penelitian dan penulisan karya ilmiah, maka buku ini hadir terutama di lingkungan Sekolah Tinggi Agama Kristen (STAK) Arastamar Grimenawa Jayapura.

Ada pun tujuan buku ini adalah:

Pertama, memberikan panduan atau pedoman baku seperti yang telah ditetapkan oleh Ketua STAK Arastamar Jayapura-kepadapara mahasiswa tingkat akhir yang menyusun skripsi dan melakukan penelitian, agar mereka dapat menyusun skripsi berdasarkan ketentuan yang berlaku.

Kedua, mengarahkan para mahasiswa untuk memperhatikan berbagai aspek penting dalam penelitian dan penyusunan skripsi sehingga hasilnya memuaskan.

Ketiga, mendorong mahasiswa untuk mematuhi ramburambu yang ditetapkan pihak sekolah agar proses penelitian dan proses penyusunan skripsi dapat berjalan dengan baik. Juga, para mahasiswa didorong untuk menyusun kerangka berpikir logis, sistematis, dan empirikal dari penelitian yang dilakukan.

Dengan demikian, signifikansi penyusunan skripsi dapat memberikan hasil yang maksimal tanpa melanggar aturan 
main yang telah ditetapkan. Berbagai kekeliruan, kesalahan, bahkan plagiarisme dalam proses penelitian dan penulisan, dapat saja terjadi. Namun, adalah wajib bahwa setiap mahasiswa untuk menghindari tindakan plagiarisme.

Penelitian bisa terjadi kekeliruan dan kesalahan, tetapi peneliti (para mahasiswa) harus bersikap jujur selama proses penelitian dan penulisan. Hal ini berkaitan dengan nama baik mahasiswa dan institusi (lembaga) di mana mahasiswa tersebut mengikuti proses pendidikan.

Berikut ini adalah hal-hal penting yang terkait dengan komprehensivitas proses penelitian dan penyusunan skripsi termasuk hal-hal mendasar dari sistem akademik, program studi, dan lembaga penyelenggara pendidikan.

Pertama, Program Studi (Prodi) adalah pelaksana akademik di bawah STAK-AGJ yang mengkoordinasikan dan/atau melaksanakan pendidikan akademik dan/atau profesional dalam satu atau seperangkat cabang ilmu pengetahuan, teknologi dan/atau kesenian.

Kedua, bagian akademik adalah unit pelaksana akademik di bawah Prodi yang melaksanakan pendidikan akademik dan/atau profesional dalam satu atau seperangkat cabang ilmu pengetahuan, teknologi dan/atau kesenian.

Ketiga, Wakil Ketua I (Waket) Bidang Akademik adalah pemimpin Akademik (yang membawahi prodi-prodi), yang dalam pelaksanaan tugas dan tanggung jawab berada di bawah Ketua STAK-AGJ.

Keempat, Kepala Program Studi (atau Ketua Jurusan) adalah pimpinan program studi yang dalam pelaksanaan tugasnya berada di bawah dan bertanggung jawab kepada 
Wakil Ketua I Bidang Akademik.

Kelima, Kepala Bagian adalah pimpinan pada bagian di bawah Prodi yang berada di bawah serta bertanggung jawab kepada Kaprodi, diangkat dan diberhentikan oleh Rektor/Ketua.

Keenam, Dosen adalah seorang yang berdasarkan pendidikan dan keahliannya diangkat oleh yayasan dengan tugas utama mengajar, melakukan penelitian, an pengabdian kepada masyarakat.

Ketujuh, Mahasiswa adalah peserta didik yang terdaftar dan belajar di STAK-AGJ.

Kedelapan, Penelitian adalah suatu usaha yang dilakukan secara sistematik dan terorganisir untuk melakukan penyelidikan secarailmiah terhadap suatu permasalahan yang dimaksudkan untuk mengungkap suatu fenomena.

Kesembilan, Judul merupakan kompas dalam menyusun skripsi dan karya ilmiah lainnya atau dapat pula dikatakan bahwa judul merupakan gambaran dari conceptual framework (kerangka kerja konseptual) suatu penelitian.

Kesepuluh, Proposal penelitian adalah suatu rencana dalam rangka pelaksanaan suatu penyelidikan danmerupakan usulan untuk dipertimbangkan dalam melakukan kegiatan penelitian.

Kesebelas, Seminar proposal adalah suatu kegiatan ilmiah untuk menyampaikan rencana usulan penelitian.

Keduabelas, Ujian adalah kegiatan penilaian untuk mengetahui derajat kemampuan mahasiswa dalam 
penguasaan materi perkuliahan atau kompetensi keilmuan pada waktu tertentu, yang berbentuk ujian skripsi/tugas akhir.

Ketigabelas, Skripsi/tugas akhir adalah karya ilmiah yang ditulis oleh mahasiswa sebagai hasil penelitian dan atau pengkajian ilmiah terhadap satu objek yang berkaitan dengan bidang ilmunya pada akhir program studi sebagai salah satu persyaratan penyelesaian program studi untuk mencapai gelar kesarjanaan/keahlian/magister.

Dari tigabelas hal-hal mendasar terkait dengan keseluruhan signifikansi legalitas dan proses penelitian, penyusunan, dan ujian skripsi, diharapkan dapat memberikan gambaran dan pemahaman yang baik sehingga menghasilkan sebuah sistem dan keteraturan mekanisme, sampai kepada kelulusan mahasiswa yang telah memenuhi semua persyaratan yang ditetapkan pihak sekolah. 
Kita tahu bahwa menulis karya ilmiah tidaklah semudah yang kita pikirkan. Pemahaman akan substansi tulisan, struktur berpikir, pemahaman akan fakta penelitian, tata cara penulisan, adalah kesatuan yang tak dapat dipisahkan. Dari situ kita dapat memahami kualitas tulisan yang dapat memberikan pengaruh bagi para pembaca dan masyarakat di mana hasil penelitian itu diterapkan.

Buku ini secara khusus menjelaskan mengenai panduan bimbingan penulisan skripsi. Panduan bimbingan ini dibuat agar mahasiswa yang sedang menyusun skripsi (hasil penelitian lapangan, perpustakaan, dan sebagainya), dapat menunjukkan kualitas tulisan itu sendiri. Dengan demikian, panduan bimbingan penulisan skripsi sangat penting dipahami dan diterapkan di perguruan tinggi.

Setiap perguruan tinggi memiliki ketentuan atau pedoman tersendiri; kadang sama dengan perguruan tinggi lainnya, dan kadang juga berbeda. Tetapi secara substansial, setiap panduan memiliki kandungan dan prinsip yang sama, tergantung metode penulisan seperti apa yang digunakan, mekanisme penulisan struktur penelitian, dan aspek-aspek lainnya yang signifikan dan suplementatif. Melihat perkembangan teknologi informasi dan ilm pengetahuan, kita tersadar bahwa kita harus terus mengasah kemampuan untuk dapat bersaing di dunia kerja. Hasil-hasil penelitian para mahasiswa mencerminkan kemampuan dasar dan kemampuan intelektualnya sebagai bekal di kemudian hari. Jika hasil penelitiannya kurang baik, maka dapat berpotensi mengurangi kapabilitas akademis dan pemahaman tentang kajian keilmuan yang digelutinya. Dunia kerja mendorong setiap orang untuk berkompetensi secara sehat, tidak hanya soal kapabilitas fisik, melainkan kapabilitas relasi, komunikasi, dan akademis. Apalagi, mahasiswa itu sendiri telah mengenyam pendidikan selama bertahun-tahun.

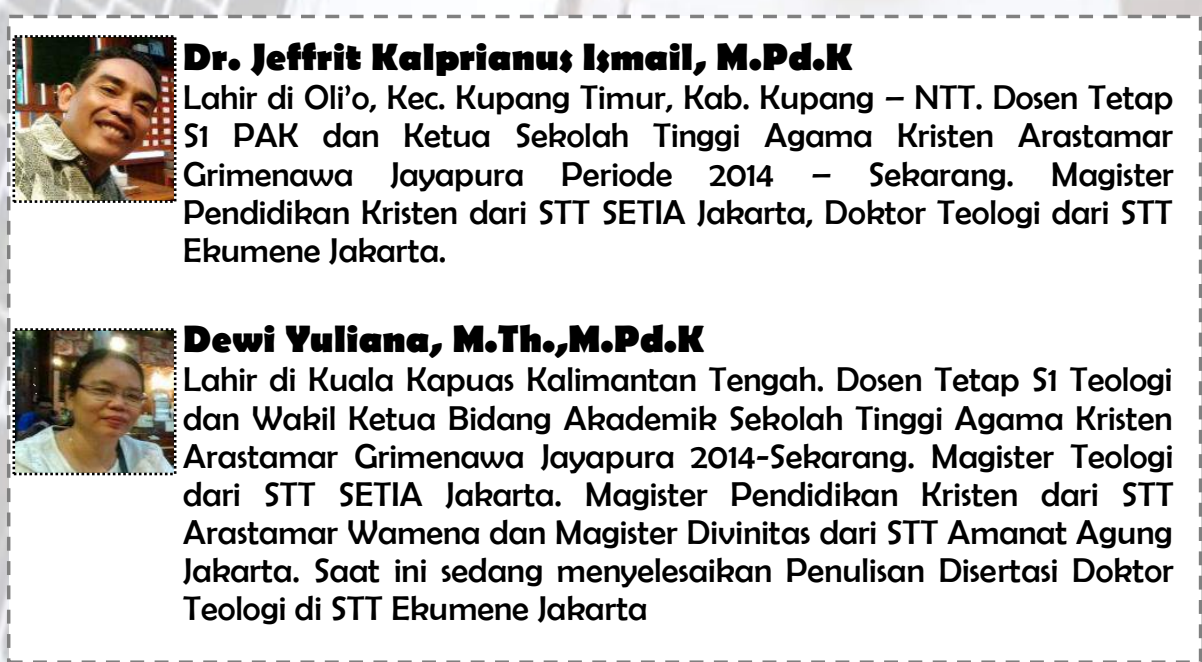

ISBN 978-623-91787-4-1
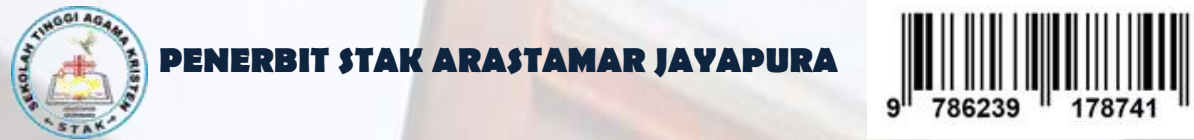